\title{
Litteratur
}

\section{Mogens Müller}

Jesu-Liv-Litteratur i Danmark. Jesusbilleder eller tidsbilleder? København: Anis 2008. 183 s. Kr. 219.

Man læser Mogens Müllers bog om den danske "Jesu-liv-litteratur” med taknemmelighed. Müller er nemlig - efter Frederik Torms bidrag (1918), som især byggede på Emil Rasmussen, der også nævnes af Albert Schweitzer - den første videnskabelige teolog, der fremstiller og kritisk reflekterer sidste århundredes danske Jesu-liv-litteratur. Samtidig bliver man mindet om Schweitzers bog (Geschichte der Leben-Jesu-Forschung, 1906/1913).

Schweitzers tanke var bl.a., at han ville vise de forskellige hermeneutiske aporier i den historiske Jesus-forskning, der begyndte med Reimarus (1778) og Semler (1779). I slutningen af sin bog beklager Schweitzer, at alle de gennemgåede historiske, rationalistiske og liberale forsøg på at aktualisere den historiske Jesus snarere har skabt en stor distance til "Jesus" end bidraget til en brugbar Jesus-fortolkning (Jesus "ging an unserer Zeit vorüber und kehrte in die seinige zurück”). Ifølge Schweitzer er det bedre, om Jesus bliver en person, som vi i stedet - og måske udelukkende - kan have et mystisk forhold til ("Jesusmystik").

Er der også aporier i den danske Jesu-liv-litteratur, som Müller beskriver? Jeg mener, man kan finde nogle. Men først kort om Müllers tilgang. Ifølge Müller skal man betragte alle forsøg på at skabe Jesus-billeder ud fra følgende spørgsmål: "hvordan de enkelte [forfattere, E-MB] har opfattet Jesus som person, hvordan de har karakteriseret Jesu opfattelse af sig selv, om deres syn på kildernes egnethed til at komme med noget sikkert svar på dette spørgsmål..., samt endelig om deres forståelse af forholdet mellem den historiske skikkelse Jesus af Nazaret og kirkens Kristus" (18f.). Müller selv begynder efter denne indledning - sin fremstilling med Frederik Torm og hans "konservative udgangspunkt". Efter dette nævner han forskellige repræsentanter og strømninger af Jesu-liv-litteraturen, såsom liberalteologien ( $\mathrm{fx}$ Henning Jensen), O. Thune Jacobsen og diverse religionshistoriske bidrag. I de sidste tre kapitler giver Müller et overblik over "tiden fra 1945 til i dag”, "Danske Jesus-bøger siden 1945" med den vigtige henvisning til Børge Diderichsens Jesus-fremstilling fra 1962 og "Fageksegesens Jesus-opfattelser", som hovedsagelig blev publiceret i leksikon-artikler og ikke i selvstændige monografier.

Alt i alt får man et godt og meget interessant indtryk af Jesu-liv-litteraturens fortolkningshistorie og -kultur i Danmark, fordi man kan se, hvilke forfattere, der i hvilke tidsperioder og med hvilke baggrunde og interesser har givet bestemte Jesus-fortolkninger, som frem for alt skulle bruges i det offentlige og kirkelige rum.

Derudover kan Müllers fremstilling hjælpe den eksegetiske forskning til både at forstå sin fortid i forskningshistorisk henseende, og til at fortsætte den 
"selvrefleksive" proces i samfundet - ikke kun om Jesu-liv-fortolkningens historie, men frem for alt også om eksegesens nutid og fremtid. Hvorfor det?

Jeg vil referere to aspekter, som ikke kun nævnes i forbifarten hos Müller. For det første er det ikke tilfældigt, at Müller taler om Jesu-liv-litteratur og ikke om "Jesu-liv-forskning", som Schweitzer gjorde det. Müller selv nævner implicit grunden: Ud over Børge Diderichsen har ingen universitetsansatte fageksegeter fremstillet "den historiske Jesus" i bogform. Jesu-liv-litteraturen efter Diderichsen blev skrevet af præster (fx Niels Nøjgaard), lærere ( $\mathrm{fx}$ Ebbe Gudmand-Høyer), journalister og forfattere (fx Erik Nørgaard), men ikke af videnskabelige eksegeter. Det faktum fortæller ganske vist meget om samfundets interesse $i$ at skrive om religiøse, fx nytestamentlige emner. Men det må også fortælle meget om situationen i den eksegetiske basisforskning - $\mathrm{i}$ hvert fald indtil Per Bilde for nylig har forandret denne situation med sin vigtige bog Den historiske Jesus, som udkom kort efter Müllers fremstilling 2008, men uafhængigt af Müllers situationsanalyse.

For det andet konstaterer Müller, at det ikke var selvstændighed, der karakteriserede Jesu-liv-litteraturen i Danmark, der på nær enkelte undtagelser derfor heller ikke opnåede udbredelse i udlandet. Så må datidens Jesu-liv-litteratur i stedet give et billede af, hvad der skete (eller ikke skete) med den (historiske) Jesus i Danmark: Blev debatten om den historiske Jesus i virkeligheden vigtigere i det offentlige eller kirkelige rum end blandt eksegeter på universitetet?

På den ene side kunne det være en fordel, fordi man dermed ikke er endt i de aporier, som Schweitzer i sit tilbageblik fremhævede som et problematisk resultat af den historisk-akademiske Jesus-forskning. På den anden side, kunne man godt ønske sig, at Danmark udbyggede sit fagvidenskabelige bidrag ikke kun til den internationale Jesus-forskning, men til eksegesen generelt - ved $\mathrm{fx}$ at betragte faget på universitetet som en teologisk basis-opgave.

Eve-Marie Becker

\section{Morten Thing}

De russiske jøder i København 1882-1943. København: Gyldendals forlag 2008, 656 s. ill. Kr. 399 (vejl.).

I årene 1882-1914 ankom 10.000-12.000 russiske jøder til Danmark på flugt fra forfølgelser, myrderier, antijødiske love, elendige sociale forhold, angst for militærtjeneste i den japansk-russiske krig. Langt de fleste rejste efter kortere eller længere tid videre til USA, England og andre lande, men omkring 3.000 blev i København. Det er deres historie, som forfatteren, dr.phil. og forskningsbibliotekar, her beskriver. Bogen falder i tre dele. I første del (1882-1920) behandles den betydning, som det officielle Danmarks modtagelse af jøderne havde for lovgivningen og holdningen til de fremmede. Lige så vigtig, og på flere måder skæbnesvanger, blev reaktionen i det etablerede danske jødiske samfund. Her så mange på indvandrerne med stor skepsis og afstandtagen, medens andre udførte et enormt hjælpearbejde. De 